\title{
Investigating the supply chain drivers and barriers in the tourism industry in Pretoria
}

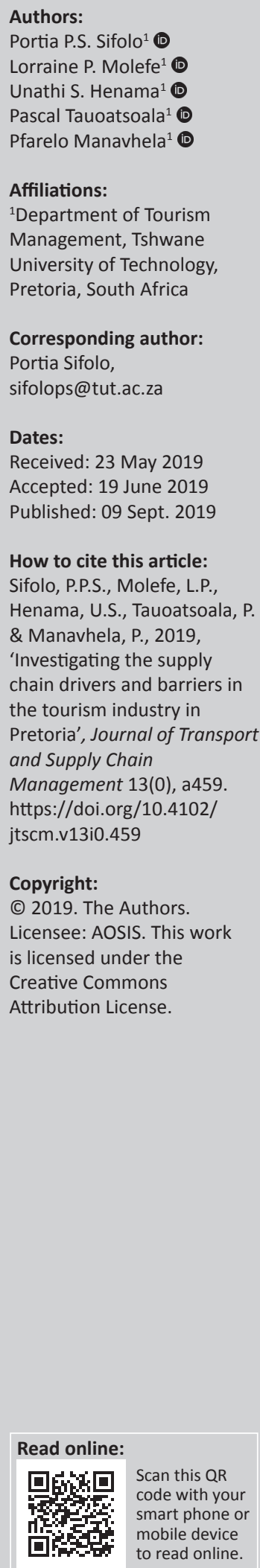

\begin{abstract}
Background: The cross-cutting nature of the tourism industry is one of the defining features or characteristics of the sector. There is a high rate of interdependence in the tourism industry; hence, it is dubbed to be having a multiplier effect (direct, indirect and induced).
\end{abstract}

Objectives: The aim of the study is to investigate the supply chain (SC) drivers and barriers of the businesses operating in the tourism industry in Pretoria.

Method: A self-administered questionnaire was used to identify the drivers and barriers within the tourism SC (TSC). Convenience sampling was implemented among 179 businesses operating in Pretoria.

Results: The results revealed that customer relationship management is an SC driver for tourism operation in Pretoria. The barriers incorporate issues such as being insensitive to the environment, not developing environmental-friendly SCs and logistics practices and not being able to assess the performance against criteria defined in the organisation's policy. Moreover, the study presents the mitigation plan approach to deal with the TSC barriers in the near future.

Conclusion: Innovation that strengthens inter-sectoral planning and collaboration is pivotal for effective coordination.

Keywords: tourism supply chain; drivers; barriers; supply chain practices; mitigation plans.

\section{Introduction}

The nature of the tourism industry is that it traverses various industries and sectors that cater for the needs of tourists. Tourism and hospitality industries are characterised by many small firms worldwide whose ultimate objective is to ensure maximum profit. For example, in 2008, the tourism sector witnessed continuous growth from 100 million jobs (3.7\% of total jobs), to 120 million jobs (about $3.8 \%$ of total employment) in 2017; the number was projected to grow to 140 million jobs (4.2\% of total employment) by 2028 (World Travel \& Tourism Council [WTTC] 2018).

The economic contribution of the tourism sector cannot be over-emphasised. There are often challenges associated with the attainment of the desired profit by any business or company. For instance, one often has to strike a balance between supply and demand without necessarily compromising the quality. Another critical aspect in the business is accountability. In this regard and in order to be successful, any company or business is expected to also have a sense of balance of the triple bottom line. This balance involves being socially, environmentally and economically accountable to all its stakeholders. In supply chain management (SCM), this is often referred as the 'triple bottom line' concept because it covers the three main aspects of sustainability: environmental performance, social responsibility and economic contribution. Therefore, in an attempt to identify the drivers and barriers of the tourism supply chain (TSC) among businesses in Pretoria, an exploratory investigation study is desirable.

\section{Tourism background in South Africa}

The City of Tshwane is an administrative capital of the country where the Union buildings (the offices of the South African President) are located. It has a rich history. The city hosts the largest number of embassies in the world after Washington, DC (travelstartblog 2017). There are many tourist attractions in Pretoria including the Pretoria Zoo, Freedom Park, the Voortrekker Monument, just to mention a few. The status quo of Tshwane Tourism consists of a variety of components including tourism products, marketing, infrastructure, human resource, small micro medium enterprise (SMME) and entrepreneurial development and investment development plans. 
An economic analysis by Statistics South Africa (2018) identifies tourism products as the following:

- accommodation for visitors

- restaurants and similar services

- railway passenger transport services

- water passenger transport services

- air passenger transport services

- transport equipment rental

- travel agencies and other reservation services

- cultural services

- sports and recreational services

- tourism-connected products and no-specific products. (p. 13)

The aforementioned are components that are featured in the tourism value chain in South Africa. These tourism products also serve as enablers and drivers for tourism in the Tshwane area. According to Hove-Sibanda and Pooe (2018), there is a relationship between company performance and supply chain (SC) performance, and this has prompted managers, practitioners and researchers alike to seek a better understanding of the performance of SCs.

The tourism industry in South Africa is largely composed of SMMEs, and it is where most entrepreneurial activity takes place (Nieman \& Niewehuizen 2019). The SMMEs generate $35 \%$ of the gross domestic product (GDP). However, entrepreneurs and small businesses experience challenges that prohibit coordination and effective implementation of sustainable SC (SSC) (Molefe et al. 2018). Because of the fact that scholars such as Schumpeter (1934) and Casson (2009) link entrepreneurs to economic development, perhaps delving on the concept of economic development will be beneficial especially because the South African government has identified the tourism industry as a critical sector that can boost economic development and reduce unemployment (Binns \& Nel 2002 cited in Sifolo 2015).

\section{Local economic development}

There have been several interpretations on the concept of local economic development in academia and in practice. There is a school of thought among academics and businesses that local economic development is closely linked to propoor tourism. For example, Rogerson (2013) has been an advocate for pro-poor tourism in South Africa as a local economic development initiative to expand the participation of poor people in the tourism economy. In his research on township tourism, Rogerson (2013) cogitates that township tourism is a potential vehicle for inclusive urban tourism and/or pro-poor tourism development.

Although the focus is not on townships but local economic development, Rogerson's (2006) sentiments have been vastly shared throughout the developing world, that the small and medium enterprises (SMEs) are regarded as the seed bed and engine for economic development, poverty alleviation, employment creation and socio-political development.
Therefore, addressing the barriers that face SMMEs and maximising a wide range of employment, self-employment and informal sector opportunities is paramount. The sentiments of local development and transformation remain at the top of the government agenda in South Africa; hence, this study focuses on the tourism operations SC drivers and barriers in this developing country.

The emphasis of this study is on local economic development as an approach to bring about transformation among tourism operations. Sharpley and Telfer (2004:84) argue that economic development is a process of economic transition that involves the structural transformation of an economy and a growth of the real output of an economy over time. This study is timely because according to the annual report 2017/2018 of South African Tourism, there are supply-side constraints facing the country such as insufficient accommodation options as well as a lack of supply; these constraints can either be a barrier towards a coherent supply-side of the tourism businesses. In other words, one may argue that, through local economic development, economic transformation is inevitable.

Tourism supply chain is vast and demands numerous stakeholders for it to be effective and efficient. Hence, social inclusion is critical. The inclusion and empowerment of women in economic activities is deemed as a necessity to ensure sustainable economic development (Department of Women 2015). Social inclusion in a form of economic activity forms part of transforming the tourism industry. Drawing from Mugume's (2010:12) inferences, financial institutions are central to economic development and growth. Economic development occurs with sustained growth from a simple, low-income economy to a modern, high-income economy; as a result, economic activities should be geared to creating an economic base. An increase in formal incentives leads to a significant increase in economic development (Rodrik et al. 2004; Xu 2011). Perhaps, unpacking the concept of SC as an inclusive approach to ensure maximum economic development benefits is critical.

\section{Supply chain management}

Supply chain refers to clusters of organisations that pass goods from one organisation to the next (Bizana, Naude \& Ambe 2015; Mentzer et al. 2001). Supply chain management is the design and management of seamless, value-added processes across organisational boundaries to meet the real needs of the end customer (Fawcett et al. 2007). Hugo, Badenhorst-Weiss and Van Biljon (2004) define SCM as a philosophy of management intended to integrate a system of upstream connections in an organisation with downstream connections by implementing precise procedures and duties that will eventually generate and maximise satisfaction for the consumer through goods and services. Despite several definitions, Hugo, Badenhorst-Weiss and Van Biljon's definition resonates with this study because the focus of the definition is more on valuable partnerships and the effective integrated system of goods and services to ensure service excellence within the TSC. 
The role and nature of SCM research is evolving because companies are increasingly embedded in complex, dynamic, globally dispersed SCs with new challenges. Given the multidisciplinary and multi-level nature, the performance measure of TSC is essential. The SC is the new frontier in environmental responsibility - an area rich with opportunity that remains mostly unexplored, where a number of pathfinders are starting to show others the value that can be found. Sifolo (2015) advocates for SCM within the tourism sphere of influence to strengthen regional, national, provincial and local partnerships in South Africa. In this study, SCM is favoured because of its influence to strengthen SCM in tourism operations in Pretoria because SCM is famous for promoting coherence and coordination.

\section{Drivers and barriers to tourism supply chain}

Organisations face barriers to sustainable SCM (SSCM). These barriers can be either internal or external challenges to the organisation. A combination of tourism products and services together with coherence and coordination among operations can be regarded as drivers of SSCM.

\section{Drivers of supply chain}

Cooper et al. (2008) identify future drivers of the external environment for tourism as trends and variables that are interlinked and are mutually re-enforcing tourism. Some trends are outside the control of tourism; for example, social change (demographic and social trends), international and political drivers of change (trade blocs and regionalism, globalisation), safety, security and risk as well as climate change (Cooper et al. 2008).

Figure 1 and 2 present the summary of the study conducted by Tay et al. (2015) on drivers or enablers of sustainable supply chain practices. The figures may not be ideal to explain the future drivers of TSC at this stage because of the scope of the study. However, a review on the drivers and barriers towards the implementation of the SSCM will be looked at in this study. Tay et al. (2015) covered the following internal drivers or enablers towards sustainable practices.

A study conducted by Molefe et al. (2018) on tourism supply chain practices (TSCPs) among tourism operations revealed that establishing a long-term relationship with suppliers is critical towards the performance of the entire chain. Hence, striking a balance between supply and demand without necessarily compromising the quality and being socially, environmentally and economically accountable to all the stakeholders is what drives TSC. One may concur that the tourism operations in Pretoria must be aware of the drivers and benefits associated with operating within an effective SC. This coordination and collaboration makes it easy to manage the chain if implemented correctly. For operations to have a competitive advantage, there should be an effective integration and management of the network of tourism organisations with customer benefits in mind.

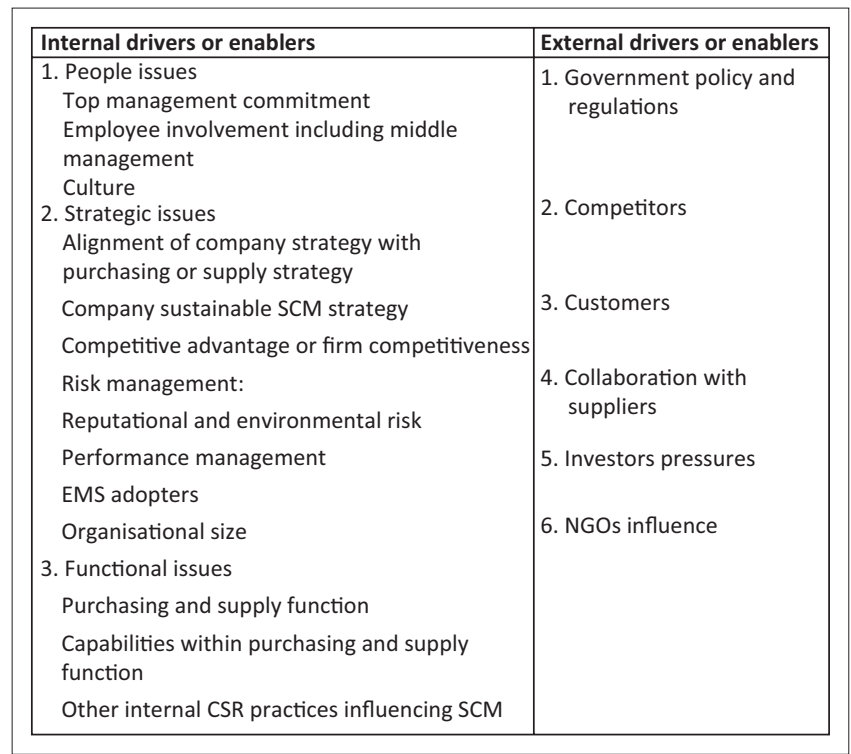

Source: Adapted from Tay, M.Y., Rahman, A.A., Aziz, Y.A. \& Sidek, S., 2015, 'A review on drivers and barriers towards sustainable supply chain practices', International Journal of Social Science and Humanity 5(10), 892. https://doi.org/10.7763/IJSSH.2015.V5.575 SCM, supply chain management; EMS, environmental management system; CSR, corporate social responsibility; NGO, non-governmental organisation.

FIGURE 1: Drivers towards sustainable practices.

\begin{tabular}{|l|l|}
\hline Internal barriers & External barriers \\
\hline $\begin{array}{l}\text { 1. People issues lack of management } \\
\text { commitment }\end{array}$ & $\begin{array}{l}\text { 1. Government regulation } \\
\text { 2. Strategic issues }\end{array}$ \\
$\begin{array}{l}\text { 2. Competitors } \\
\text { Cesources: cost }\end{array}$ & $\begin{array}{l}\text { Competitive pressures } \\
\text { Performance measurement: traditional }\end{array}$ \\
accounting methods & Consumers desire for lower \\
organisational size: smaller firms & Poor supplier commitment \\
Financial,technical, information, managerial & 4. Media \\
and organisational & Green wash \\
3. Functional issues & 5. Sectoral less regulated \\
Purchasing and supply function: & industries \\
Lack of training & 6. Organisation \\
Lack of understanding of how to incorporate & Policy and market issues \\
in purchasing & 7. Technology \\
Other SCM priorities & ICT \\
Lack ofcorporate structures and processes & \\
\hline
\end{tabular}

Source: Adapted from Tay, M.Y., Rahman, A.A., Aziz, Y.A. \& Sidek, S., 2015, 'A review on drivers and barriers towards sustainable supply chain practices', International Journal of Social Science and Humanity 5(10), 892. https://doi.org/10.7763/IJSSH.2015.V5.575

SCM, supply chain management; ICT, information communication technology.

FIGURE 2: Barriers towards sustainable practices.

Offering different components of tourism products and services at a specific tourism destination requires seamless distribution and the effective marketing of tourism services.

\section{Barriers of supply chain}

There are several barriers in the TSC in South Africa. Noncompliance with SCM legislation particularly in different municipalities where the tourism operations exist (Auditor General 2016:6) is among the critical barriers because the municipalities are responsible for the infrastructure and service delivery in general. The misalignment of skills or the lack of career pathing or progression in the education and training system for the tourism workforce may be a barrier towards achieving effective SC. Fraud and corruption and other administrative malpractices within government 
hamper SCM (Ambe \& Badenhorst-Weiss 2012:11010) as well as inadequate monitoring and evaluation mechanisms that may lead to other problems such as irregular expenditure (Auditor General 2014:19). To add to the list of barriers, Figure 2 presents the barriers towards sustainable practices. It is important to note that the barriers presented below are not inclusive of all the barriers within the TSC.

The internal barriers normally covered include a lack of supportive corporate structures and processes, a lack of management commitment and a reliance on traditional accounting methods, which do not facilitate reporting on the triple bottom line (Tay et al. 2015: 894). Sometimes, the barriers translate into risks.

According to Nhamo (2010:257), there are three risks associated with unsustainable SC and SCM, namely reputational risks, physical risks and regulatory risks.

\section{Reputational risks}

It is important for the company to protect its reputation. This can be performed in many ways. One of them is meeting the customer's demands especially because the demand for better quality products and services is increasing among consumers, especially the affluent ones. Supply chain management is about meeting the demands of the customers first, whilst it is important to ensure that the inflow and outflow of information are not distorted between the customers, suppliers, manufacturers, distributors, and so on. This applies in the tourism context.

\section{Physical risks}

Physical risks can be any risks that are caused by men: global warming, flooded raw material resources' sites, fire hazards, frost hazards, droughts, heat waves and occupational health and safety issues, collapsed infrastructure, and so on. In the tourism sector, many tourism destinations are located in areas that are exposed to various natural hazards such as tsunamis, volcanic eruptions and high winds. Several authors have referred to climate change as one of the biggest threats in our lifetime (Rogerson 2018; Sifolo \& Henama 2017) because of the effect on sustainability of the tourism sector globally. Climate change has negative impacts at the destination area and affects the standard of living and quality of life for the host community.

\section{Regulatory risks}

Regulatory risks involve the rules and regulations by government, as well as the innovation policies of the company. Although the risks fall beyond the scope of this study, it is posited that they may affect the drivers of TSC in Pretoria. The study conducted by Nguyen, Imamura and Iuchi (2016) revealed that long-term solutions should include the input of multiple stakeholders striving towards a working solution that is constantly updated through feedback loops. The mitigation plan approach to deal with the TSC barriers in the near future must utilise non-structural long-term solution approaches because TSC ensures company sustainability and long-term survival. The study on E-collaboration SCP by Hove-Sibanda and Pooe (2017) suggests that SC partnering firms need to effectively implement their intra-firm SCP of supply chain planning, just in time (JIT) production and planning systems, as well as supply flexibility practices, which plays a major role in reducing the SC risks and costs through standardising SC processes.

\section{Results}

A self-administered questionnaire was the main instrument used to obtain the data for the study between July and October 2017 from the SMMEs in Pretoria. The questionnaire had two sections. The first section contained questions on the demographic characteristics of the tourism operations that participated in the study. These questions were measured on both nominal and interval scales. The second part of the questionnaire consisted of measurement items for the constructs used in the study. These items were selected from previously validated aspects of sustainability (environmental performance, social responsibility and economic contribution). The purpose was to identify the drivers and barriers of the TSC among businesses in Pretoria. This study is exploratory in its nature.

\section{Sampling and data collection}

The population targeted included small, medium and large tourism operations in Pretoria, which is in the City of Tshwane. From the population of 616 tourism-related businesses registered under the City of Tshwane (which consist of places in and around Pretoria), data were gathered successfully from 179 conveniently sampled businesses. Figure 3 presents the descriptive statistics from the sample.

About 28.09\% (50) of the tourism operations that participated in the study were from travel organisations and bookings and accommodation $25.28 \%$ (45). Food and beverage serving activities were $14.04 \%$ (25) and transportation was $13.48 \%$ (24). Handicraft at $2.81 \%$ (5), operations and tourism assets in the destination at $2.25(4 \%)$ were the least of the participants in Pretoria. The business operations that participated in the study are similar to the tourism products as identified in the economic analysis by Statistics South Africa (2018); in other words, the tourism products available in Pretoria are among those featured in the tourism value chain in South Africa.

According to the National Small business Amendment Act (2003), a business is considered small or micro in size if the total number of full-time paid employees is 50 or less. From the total number of 179 participants, there were 88 tourism operations that have less than 49 employees (49\%) who participated in the study. This was followed by 40 tourism operations that employ 50-100 employees (22\%). There were 51 tourism operations that indicated that they employ more 


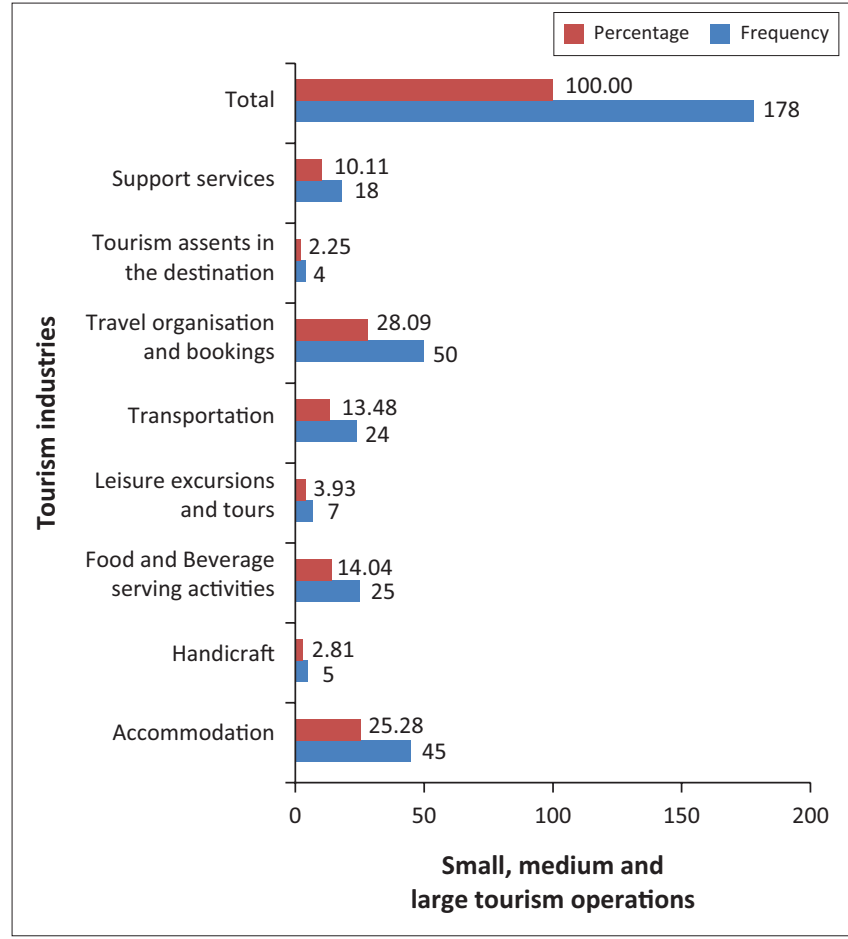

FIGURE 3: Descriptive statistics of the tourism operations in Pretoria.

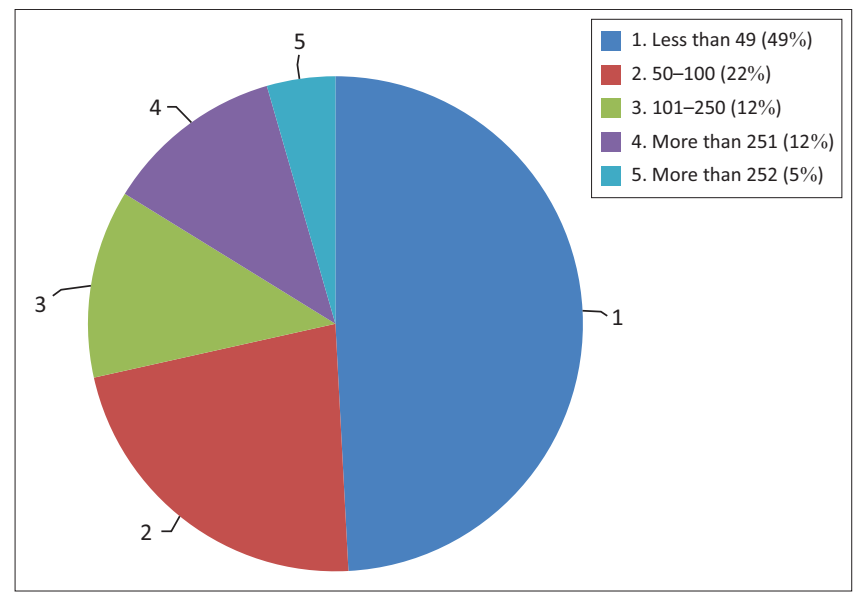

FIGURE 4: Total number of employees in tourism operations.

than 101 (29\%) employees. In other words, there are more small and micro-tourism businesses operating in the TSC in Pretoria than larger ones.

The survival rate of SMEs is relatively low worldwide (Ligthelm \& Masuku 2003). The survival rate can be determined by the number of years a business has been in operation. Figure 5 presents the number of years the tourism operations have been to business in Pretoria.

The results indicate that from 179 tourism businesses, 51 (28.98\%) that participated in the study have been operating for 11-20 years followed by 40 (22.73\%) businesses that have been operating for $2-5$ year businesses as well as $39(22.16 \%)$ that have been operating for 6-10 years. The following section focuses on the discussion and presents the descriptive statistics.

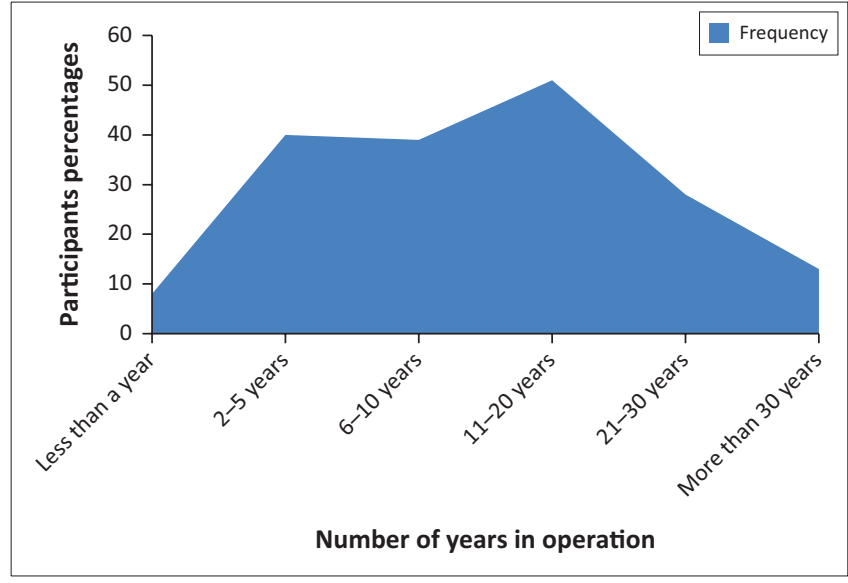

FIGURE 5: Total number of years the business has been operating.

\section{Discussions}

The Statistical Package for the Social Sciences (SPSS) version 24 was used to analyse the data. The statistical tool employed in this study was as follows: (1) a Cronbach's alpha coefficient was used to calculate the reliability of the questionnaire. (2) A five-point Likert scale with anchors ranging from ' 1 ' (strongly disagree) to ' 5 ' (strongly agree) was used to score the levels of drivers and barriers on SCPs among tourism operations in Pretoria. (3) Mean ( $x$ ) and standard deviation (SD) were used to calculate the average level of sustainable tourism SCPs (STSCPs). The highest mean score $(x)$ reflected that the participants apply the STSCP in their tourism operations. Similarly, the lowest mean score showed that they do not apply the STSCP. The SD depicted the spread or dispersion of the scores of the respondents within the group.

The descriptive statistics in Table 1 shows the mean and SD values of variables which were obtained from the empirical study. Below are the detailed SC drivers and barriers of tourism operations in Pretoria.

As shown in Table 1, most tourism operations in Pretoria rated customer relationship management variables as important SSC practices. The results (Table 2) indicate that the tourism operations SC drivers in Pretoria are social media $(x=4.56, \mathrm{SD}=0.768)$, email $(x=4.24, \mathrm{SD}=1.012)$ and the feedback system in place or frequent follow-up with the customers $x=4.00, \mathrm{SD}=0.913)$, respectively.

However, the SC barriers in this study are that the tourism operators consider some form of recycling $(x=0.88, \mathrm{SD}=$ 1.590) as not important. Another barrier is that tourism bodies in the area hardly share knowledge with other tourism stakeholders $(x=2.52, \mathrm{SD}=1.159)$ followed by exchanging information within tourism chain timeously $(x=2.56, \mathrm{SD}=$ $1.083)$ and assessing the performance of a sample of suppliers against criteria defined in the company's policy $(x=2.56$, $\mathrm{SD}=1.193)$.

Although the risks fall beyond the scope of this study, it is posited that the SC barriers among tourism operations in 
TABLE 1: Tourism operations supply chain drivers and barriers.

\begin{tabular}{|c|c|c|c|}
\hline Measured variables & Tourism supply chain management practices & Mean value & Std. deviation \\
\hline \multirow{8}{*}{$\begin{array}{l}\text { Sustainable supply } \\
\text { chain performance }\end{array}$} & The organisation has sufficient tourism suppliers & 3.40 & 1.190 \\
\hline & The organisation works with an intermediary & 3.60 & 0.866 \\
\hline & The organisation strives to establish a long-term relationship with its suppliers & 3.88 & 0.881 \\
\hline & The organisation includes its key suppliers in its planning and goal setting activities & 3.68 & 0.988 \\
\hline & The organisation works only with suppliers registered or affiliated to tourism bodies suppliers & 3.08 & 1.077 \\
\hline & The organisation works with any supplier that provides low costs & 3.52 & 0.963 \\
\hline & Business solves problems jointly with its suppliers & 3.48 & 0.872 \\
\hline & Frequently interacts with other tourism stakeholders & 3.68 & 0.802 \\
\hline \multirow{8}{*}{$\begin{array}{l}\text { Sustainable supply } \\
\text { chain practice }\end{array}$} & Respond to the set tourism standards & 3.64 & 0.995 \\
\hline & There is a clear company policy on environmental management & 3.64 & 0.810 \\
\hline & The company engages in some form of recycling & 0.88 & 1.590 \\
\hline & The organisation applies responsible tourism policy & 3.68 & 1.215 \\
\hline & The organisation has respect for social dialogue with the employees & 3.72 & 0.737 \\
\hline & We raise awareness on sustainability issues among suppliers & 3.60 & 0.645 \\
\hline & The organisation considers standard environmental-, social- and economic-related issues from the suppliers & 3.28 & 0.980 \\
\hline & We offer incentives to sustainable suppliers to recognise product or service quality & 3.40 & 1.118 \\
\hline \multirow{5}{*}{$\begin{array}{l}\text { Customer relationship } \\
\text { management }\end{array}$} & The organisation has a feedback system in place or frequent follow-up with its customers & 4.00 & 0.913 \\
\hline & Email & 4.24 & 1.012 \\
\hline & Visitors book & 3.64 & 1.469 \\
\hline & Social media & 4.56 & 0.768 \\
\hline & The organisation frequently measures and evaluates customer expectation & 3.84 & 1.106 \\
\hline \multirow{6}{*}{$\begin{array}{l}\text { Integrated supply } \\
\text { chain }\end{array}$} & Our organisation regularly shares information relevant to our suppliers & 3.56 & 0.651 \\
\hline & We inform our suppliers about the industry-related developments & 3.44 & 0.712 \\
\hline & Information is shared with the relevant members in the entire tourism chain (including all relevant sectors) & 3.04 & 0.978 \\
\hline & The relevant tourism bodies in the area share knowledge with other tourism stakeholders & 2.52 & 1.159 \\
\hline & The organisation employees keep each other informed about the changes in the industry for planning purposes & 2.76 & 1.091 \\
\hline & Information exchange within the tourism chain is timely & 2.56 & 1.083 \\
\hline \multirow{8}{*}{$\begin{array}{l}\text { Supply chain } \\
\text { performance }\end{array}$} & Ability to accommodate customer's demands & 3.92 & 0.909 \\
\hline & Maintains a relationship that nurtures dependable service suppliers & 3.60 & 0.816 \\
\hline & Ability to respond to new competitors effectively & 3.80 & 0.645 \\
\hline & Ability to respond to new products or services & 3.52 & 0.770 \\
\hline & There is return on investment when working with tourism stakeholders & 3.12 & 1.013 \\
\hline & There are benefits of being affiliated with the tourism stakeholders in my area & 3.04 & 1.020 \\
\hline & There are incentives by virtue of being a tourism member in our area & 2.76 & 1.128 \\
\hline & We assess the performance of a sample of suppliers against criteria defined in our policy & 2.56 & 1.193 \\
\hline
\end{tabular}

Note: 1 represents 'strongly disagree' and 5 represents 'strongly agree'.

Std., standard.

TABLE 2: Tourism operations supply chain drivers and barriers in Tshwane. Tourism operations supply chain drivers Tourism operations supply chain barriers Social media Assessing the performance of a sample of suppliers against criteria defined in the organisations' policy

Exchanging the information within tourism chain is timely

Email

The relevant tourism bodies in the area hardly share knowledge with other tourism stakeholders

The company does not engage in some form of recycling

Pretoria may affect the drivers of TSC in Pretoria. For example, issues like not engaging in recycling can cause a reputational risk in an organisation or the destination in many ways. For example, environmentalists have influenced companies' perceptions and practices on SCs (Holt \& Ghobadian 2009:933) to develop SCs and logistics practices sensitive to the environment (Walker, Di Sisto \& McBain 2008:69). If the customer's demands for better quality products and services that are environmentally friendly are not met, this may leave a bitter taste in the environmentalist stakeholders, months such as customers who may be the suppliers' manufacturers, distributors, and so on. It is therefore important for the company to protect its reputation to ensure that the inflow and outflow of information are not distorted. Hence, Walker et al. (2008:69) call for the SCs and logistics practices that are sensitive to the environment.

Not engaging in some form of recycling can be a physical risk to men, global warming, flooded raw material resources' sites, fire hazards, frost hazards, droughts, heat waves and occupational health and safety issues (Nhamo 2010). If a tourism operation is not able to assess the performance of a sample from suppliers against criteria defined in the organisations' policy, this can lead to a regulatory risk. Lack of monitoring and evaluation mechanisms within the value chain as well as the inability to assess performance against organisation policies can be a barrier to TSC. However, prospects for the future appear to be positive. Travel statistics 
indicate that tourism is resilient and overcomes negative factors relatively quickly.

\section{Reliability and validity}

This is a follow-up study from the TSC management practices study by Molefe et al. (2018). The reliability of a questionnaire was measured through internal consistency of items using Cronbach's coefficient alpha $(\alpha)$ where five factors had Chronbach's alphas above 0.7 with relationships of 0.89 , communication of 0.85 , customer relationships of 0.79 and value-added process of 0.83 ; only one factor had a low coefficient at 0.4322 .

Internal consistency for this study refers to the correlation between the items of the measuring construct. Thus, the Cronbach's alpha was used to measure the correlations between the items and to determine how well the items are positively related (Sekaran \& Bougie 2010:162). The Cronbach's alpha values for the instrument were 0.8906 .

\section{Limitations of the study}

Although the study is exploratory in nature, the study does not provide a full picture of all the drivers and barriers of SC in Pretoria because of uncategorised tourism products and services organisations. The number of business is not representative of all business in the City of Tshwane. The previous studies provided opportunities to unpack SC drivers and barriers among tourism operations in Pretoria. Another limitation of the study is that the sample was restricted to tourism operations, and not on other companies within the entire value chain, including agriculture. The major limitation of this type of study is the extent to which the findings can be generalised to other organisations.

\section{Conclusion}

This study has offered some valuable insight into studies on the tourism value chain through the lens of local economic development. The study offers insights on tourism supply drivers and barriers. The literature concurs that there are collaboration opportunities that exist among tourism stakeholders in the TSC in Pretoria. Innovation that strengthens inter-sectoral planning and collaboration is pivotal for effective coordination. Governance of the projects or SCs is critical. Issues such as public procurement policies to source innovative goods and services or alternative solutions to meet the communities or stakeholders needs to enhance public service delivery and their environmental performance in the TSC in Pretoria are critical.

\section{Implications and recommendations}

One may pose the question: whether collaborating with other stakeholders in the TSC means that there should be a publicprivate partnership (PPP)? An upfront comprehensive answer to the above-mentioned question does not exist; however, one may argue that PPP as a model has brought solutions when it comes to managing a successful SC in the tourism industry. According to the 2019 State of the Nation Address by the South African President Cyril Ramaphosa, an appropriate use of PPPs in infrastructure development has a good chance to produce a sustainable infrastructure with great value for money. This study argues that the answer may be based on the inclusion of stakeholders and an effective implementation of tourism SCM (TSCM). A starting point could be the skills mapping in procurement or an audit of sourcing and outsourcing of tourism products and services in Pretoria to achieve the triple bottom line in the TSC. The tourism industry has been perceived as an industry that requires semi-skills personnel because of its seasonality (Nickson 2013). This will improve the competitive advantage of the destination, because a destination succeeds or fails on the fulfilment of its brand promise, particularly in areas where there is quality assurance.

\section{Acknowledgements}

Gratitude goes to the BTech students under the Supply Chain Management project at Tshwane University of Technology and Mr. Solani Ngobeni, the Publishing Director from Centre for Scholarly Publishing Services (Pty) Ltd.

\section{Competing interests}

The authors declare that they have no financial or personal relationships that may have inappropriately influenced them in writing this article.

\section{Authors' contributions}

P.P.S.S. was the project leader. P.M. made conceptual contributions, whilst P.T. prepared the samples and calculations were performed by L.P.M., and U.S.H. co-wrote the manuscript.

\section{Funding information}

This research received no specific grant from any funding agency in the public, commercial or not-for-profit sectors.

\section{Data availability statement}

Data sharing is not applicable to this article.

\section{Disclaimer}

The views and opinions expressed in this article are those of the authors and do not necessarily reflect the official policy of position of any affiliated agency of the authors.

\section{References}

Ambe, I.M. \& Badenhorst-Weiss, J.A., 2012, 'Supply chain management challenges in the South African public sector', African Journal of Business Management 6(44), 11003-11014.

Auditor General, 2016, Integraded annual report 2016-17, viewed 30 July 2019, from https://www.gov.za/sites/default/files/gcis_document/201710/ agsaannualreport2017.pdf. 
Binns, T. \& Nel, E., 2002, 'Tourism as a local development strategy in South Africa', Geographical Journal 168(3), 235-247.

Bizana, N., Naude, M.J. \& Ambe, I.M., 2015, 'Supply chain management as a contributing factor to local government service delivery in South Africa', Journal of Contemporary Management 12(1), 664-683.

Casson, M.C., 2009, The Entrepreneur: An Economic Theory (1982), University of Illinois at Urbana-Champaign's Academy for Entrepreneurial Leadership Historical Research Reference in Entrepreneurship, SSRN, viewed 31 July 2019, from: https:// ssrn.com/abstract=1496173

Cooper, C., Fletcher, J., Fyall, A., Gilbert, D. \& Wanhill, S., 2008, Tourism principles and practice, 4th edn., Prentice Hall, Pearson, Harlow.

Department of Women, 2015, The status of women in the South African economy, Department of Women Republic of South Africa, viewed 05 July 2019, from https://www.gov.za/sites/default/files/gcis_document/201508/ statusofwomeninsaeconomy.pdf.

Fawcett, S.E., Ellram, L.M. \& Ogden, J.A., 2007, Supply chain management: From vision to implementation, Pearson Prentice Hall, Upper Saddle River, NJ.

Holt, D. \& Ghobadian, A., 2009, 'An empirical study of green supply chain management practices amongst UK manufacturers', Journal of Manufacturing Technology Management 20(7), 933-956. https://doi.org/10.1108/17410380910984212

Hove-Sibanda, P. \& Pooe, D., 2017, 'The influence of supply chain practices on supply chain collaboration', 17th International Business Conference, Dar Es Salaam, Tanzania.

Hove-Sibanda, P. \& Pooe, D., 2018, 'Enhancing supply chain performance through supply chain practices', Journal of Transport and Supply Chain Management 12(0), a400. https://doi.org/10.4102/jtscm.v12i0.400

Hugo, W.M., Badenhorst-Weiss, J.A. \& Van Biljon, E.H., 2004, Supply chain management logistics in perspective, Van Schaik, Pretoria.

Ligthelm, A.A. \& Masuku, T., 2003, Size, structure and profile of the informal retail sector in South Africa, Bureau of Market Research, University of South Africa. Pretoria

Mentzer, J., De Witt, W., Keebler, J., Min, S., Nix, N. \& Smith, C., 2001, 'Defining supply chain management', Journal of Business Logistics 22(1), 107-124. https://doi. org/10.1002/j.2158-1592.2001.tb00001.x

Modica, P.D., Altinay, L., Farmaki, A., Gursoy, D. \& Zenga, M., 2018, 'Consumer perceptions towards sustainable supply chain practices in the hospitality industry', Current Issues in Tourism 1-18.

Molefe, P.L., Tauoatsoala, P., Sifolo, P.P.S., Manavhela, P. \& Henama, U.S., 2018, 'The effects of tourism supply chain management practices on tourism operations in Pretoria, South Africa', African Journal of Hospitality, Tourism and Leisure 7(2), $1-12$.

Mugume, A., 2010, Competition and performance in Uganda's banking system, Africa Economic Research Consortium, Kampala.

Nickson, D., 2013, Human resource management for the hospitality and tourism industries, Elsevier, Oxford.

Nieman, G. \& Nieuwenhuizen, C., 2019, Entrepreneurship: A South African perspective, 4 th edn., Van Schaik Publishers, Pretoria.
Nguyen, D., Imamura, F. \& luchi, K., 2016, 'Disaster management in coastal tourism destinations: The case for transactive planning and social learning', International Review for Spatial Planning and Sustainable Development 4(2), 3-17. https://doi. org/10.14246/irspsd.4.2 3

Nhamo, G., 2010, Green economies and green jobs: Implications for South Africa, in K. Aravossis \& C.A. Brebbia (eds.), Environmental Economics and Investment Assessment III. Southampton: Witpress. 257-268, p. 257

travelstartbolg, 2017, 30 Fun Things To Do In Pretoria For Free And Under R300, viewed 18 June 2019, from www.travelstart.co.za/blog/cheap-fun-things-to-do-pretoria/.

Rodrik, D., Subramanian, A. \& Trebbi, F., 2004, 'Institutions rule: the primacy of institutions over geography and integration in economic development', Journal of Economic Growth, 9(2), pp.131-165.

Rogerson, C.M., 2006, 'Pro-poor local economic development in South Africa: The role of pro-poor tourism', Local environment 11(1), 37-60. https://doi org/10.1080/13549830500396149

Rogerson, C.M., 2013, 'Urban tourism, economic regeneration and inclusion: Evidence from South Africa', Local Economy 28(2), 188-202. https://doi. org/10.1177/0269094212463789

Rogerson, C.M., 2018, 'Innovation-driven local economic development: In search of best practice implementation for South Africa', EuroEconomica 37(2), 15-28.

Schumpeter, J.A., 1934 (2008), The Theory of Economic Development: An Inquiry into Profits, Capital, Credit, Interest and the Business Cycle, transl. from the German by Redvers Opie, New Brunswick (U.S.) and London (U.K.): Transaction Publishers.

Sekaran, U. \& Bougie, R., 2010, Research methods for business: A skill building approach, John Wiley \& Sons, Haddington.

Sifolo, P.P.S., 2015, 'A tourism theoretical gap: The case of the Northern Cape Province in South Africa', African Journal of Hospitality, Tourism and Leisure 4(1), 1-14.

Sifolo, P.P.S. \& Henama, U.S., 2017, 'Implications of climate change for tourism in Africa', GeoJournal of Tourism and Geosites 20(2), 191-198.

Sharpley, R. \& Telfer, D.J., 2004, Tourism and development concepts and issues, Channel View Publications, Canada.

Statistics South Africa., 2018, Economic analysis, Tourism Satellite Account for South Africa, final 2015 and provisional 2016 and 2017, viewed 22 July 2019, from https://www.statssa.gov.za/publications/Report-04-05-07/Report-04-05072017.pdf.

Tay, M.Y., Rahman, A.A., Aziz, Y.A. \& Sidek, S., 2015, 'A review on drivers and barriers towards sustainable supply chain practices', International Journal of Social Science and Humanity 5(10), 892. https://doi.org/10.7763/IJSSH.2015.V5.575

Walker, H., Di Sisto, L. \& McBain, D., 2008, 'Drivers and barriers to environmental supply chain management practices: Lessons from the public and private sectors', Journal of Purchasing and Supply Management 14(1), 69-85.

World Travel \& Tourism Council (WTTC), 2018, Travel \& tourism: Economic impact 2019 world, World Travel \& Tourism Council.

Xu, C., 2011, 'The Fundamental Institutions of Chinas' Reforms and Development', Journal of Economic Literature, 49(4), 1076-1151. 